\title{
Synthesis, structure, redox and spectra of green iridium complexes of tridentate azo-aromatic ligands
}

\author{
MANASHI PANDA, ${ }^{a}$ CHAYAN DAS, ${ }^{a}$ CHEN-HSIUNG HUNG ${ }^{\mathrm{b}}$ and \\ SREEBRATA GOSWAMI ${ }^{\mathrm{a}, *}$ \\ ${ }^{a}$ Department of Inorganic Chemistry, Indian Association for the Cultivation of Science, Kolkata 700032 \\ ${ }^{\mathrm{b}}$ Institute of Chemistry, Academia Sinica, Nankong, Taipei 115, Taiwan \\ e-mail: icsg@iacs.res.in
}

MS received 18 August 2006; revised 29 November 2006

\begin{abstract}
Reactions of $\mathrm{IrCl}_{3} \cdot \mathrm{H}_{2} \mathrm{O}$ with the ligands, 2-[(phenylamino)phenylazo]pyridine $\left(\mathrm{HL}^{1 \mathrm{a}}\right)$ and 2$\left[\left(p\right.\right.$-tolylamino)phenylazo]pyridine $\left(\mathrm{HL}^{1 \mathrm{~b}}\right)$ produce $\left[\operatorname{Ir}\left(\mathrm{L}^{1}\right)_{2}\right] \mathrm{Cl}\left(\mathrm{L}^{1}=\mathrm{L}^{1 \mathrm{a}},[\mathbf{1}] \mathrm{Cl}\right.$ and $\left.\mathrm{L}^{1}=\mathrm{L}^{1 \mathrm{~b}},[2] \mathrm{Cl}\right)$ along with many unidentified products. The iridium complexes have been characterized by various techniques such as X-ray crystallography, mass spectrometry, ${ }^{1} \mathrm{H}$ and ${ }^{13} \mathrm{C}$ NMR, cyclic voltammetry and absorption studies. The complex $[\mathbf{1}] \mathrm{ClO}_{4}$ crystallises in triclinic space group. The crystallographic data have been determined. Notably, the Ir-N (azo) lengths are short (av. 1.9875(4) $\AA$ ) as compared to the remaining four Ir-N lengths (av. 2.052(5) $\AA$ ). There is significant degree of ligand backbone conjugation in the coordinated ligands, which result in shortening of the $\mathrm{C}-\mathrm{N}$ lengths on the other side of the middle phenyl ring and also in lengthening of the diazo $(\mathrm{N}=\mathrm{N})$ lengths. The complexes display multiple low energy transitions ranging between 1010 and $450 \mathrm{~nm}$. These are electro active and show three reversible redox responses in the potential range, $+1.5 \mathrm{~V}$ to $-1.5 \mathrm{~V}$. The cathodic potential responses are ascribed as ligand reductions, while the redox process at the anodic potential occurs at a mixed metal-ligand (HOMO) orbital.
\end{abstract}

Keywords. Iridium complexes; azo-aromatic ligands; synthesis; X-ray structure; redox and spectral properties.

\section{Introduction}

In recent years we have been interested in the coordination chemistry of the 2-[(arylamino)phenylazo] pyridine ligand. ${ }^{1-5}$ Two positional isomers of this ligand, $\mathrm{HL}^{1}$ and $\mathrm{HL}^{2}$, were isolated ${ }^{6-8}$ by us by metalpromoted aromatic ring-amination reactions of the coordinated pyridyl-containing diazo ligand, 2-(phenylazo)pyridine (pap). The reference amine fusion reactions have been shown to be regioselective, occurring at the ortho- and para-carbons ${ }^{6,9}$ of the phenyl ring in labile and inert metal complexes of pap respectively. While the $\mathrm{o}$-aminated product, $\mathrm{HL}^{1}$, usually acts as a monoanionic tridentate $\mathrm{N}, \mathrm{N}, \mathrm{N}$ donor with dissociation of the amine proton, the $p$-aminated ligand $\mathrm{HL}^{2}$, on the other hand, coordinates as a neutral bidentate $\mathrm{N}, \mathrm{N}$-donor where the secondary amine nitrogen remains protonated and uncoordinated (scheme 1). Thus the coordination of the ligand

\footnotetext{
*For correspondence
}

$\mathrm{HL}^{2}$ is similar to that of its parent ligand pap and stabilises low valent metal ions ${ }^{4}$ by $d \pi-\pi^{*}$ (azo) back donation. Notably, the coordination behaviour of the $o$-isomer $\left(\mathrm{HL}^{1}\right)$ is completely different. The deprotonated anionic ligand $\left[\mathrm{L}^{1}\right]^{-}$has the unique combination of a strong acceptor ${ }^{10}$ azopyridine group as well as a strong electron donor ${ }^{11,12}$ secondary amido nitrogen, which act together in the stabilization of the variable valence states in the metal complexes. The coordination chemistry of this bischelating ligand $\left[\mathrm{L}^{1}\right]^{-}$has some notable features. For example, it not only stabilises uncommon low-spin states of $\mathrm{Mn}(\mathrm{II})^{7}$ and $\mathrm{Fe}(\mathrm{II})^{8}$ but also produces stable anionic azo-radical complexes ${ }^{2}$ of high valent metal ions.

In this paper, we wish to report the syntheses and properties of iridium(III) complexes of the deprotonated and anionic ligand $\left[\mathrm{L}^{1}\right]^{-}$. Our interest in this work originated from our recent results on amine fusion reactions of pap coordinated to $\operatorname{Ir}(\mathrm{III})$ and $\operatorname{Ir}(\mathrm{V})$ centres. ${ }^{13}$ The metal complexes, $\left[\mathrm{Ir}^{\mathrm{III}} \mathrm{Cl}_{2}(\mathrm{C}, \mathrm{N}-\mathrm{pap})\right.$ (N,N-pap)] and $\left[\mathrm{Ir}^{\mathrm{V}} \mathrm{Cl}_{4}(\mathrm{~N}, \mathrm{~N}-\text { pap })\right]^{+}$both being sub- 


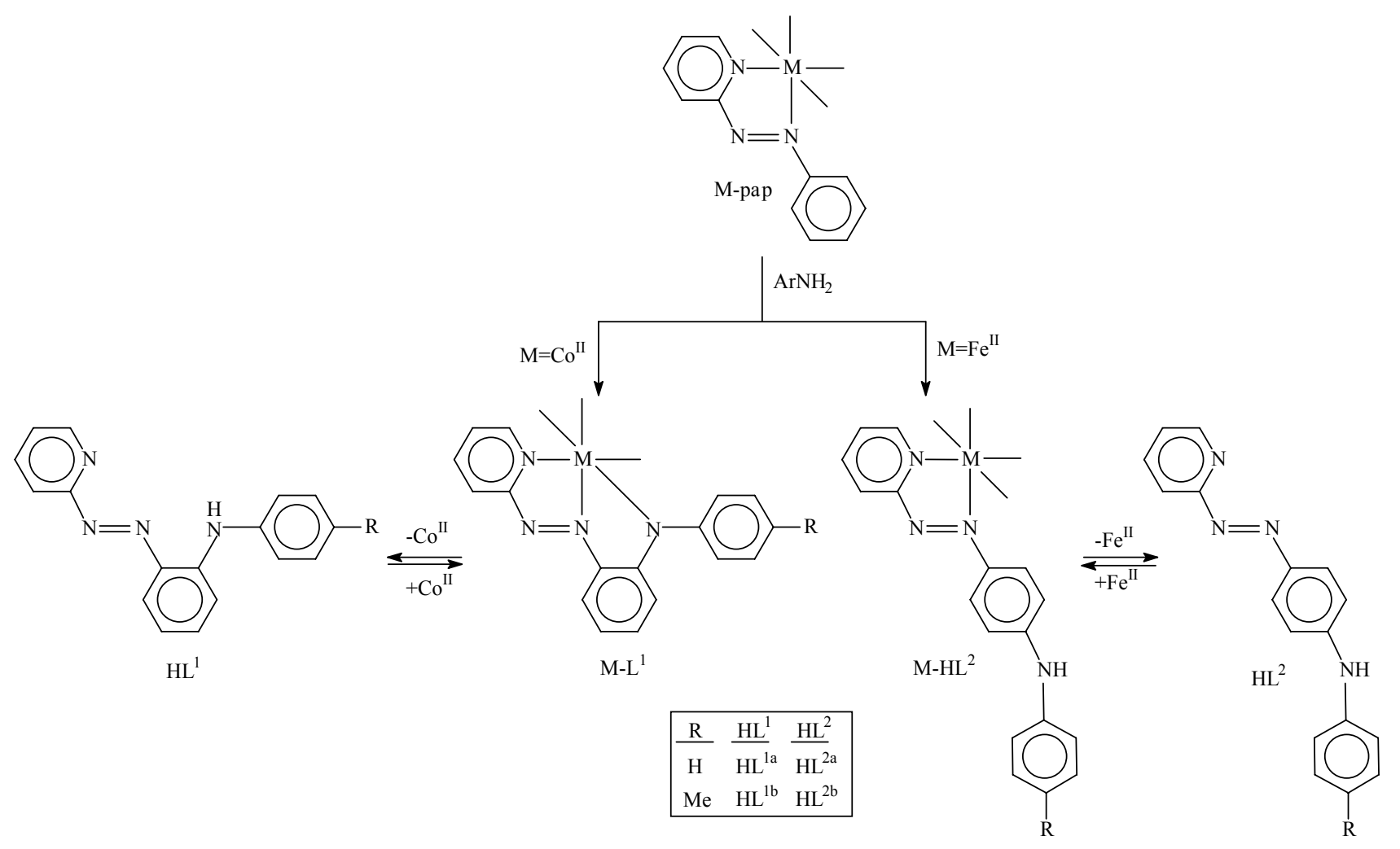

Scheme 1. Amination reaction at one coordinated di-azo ligand has been shown for clarity.

stitutionally inert, exclusively resulted in $\mathrm{C}-\mathrm{N}$ fusion at the $p$-carbon as expected. ${ }^{9}$ With this background in view and in logical continuation of our programme on the coordination chemistry of $\mathrm{HL}^{1}$, we have explored the reaction of hydrated $\mathrm{IrCl}_{3} \cdot x \mathrm{H}_{2} \mathrm{O}$ with preformed $\mathrm{HL}^{1}$. Successful isolation and complete characterization of the dark green complex $\left[\operatorname{Ir}\left(\mathrm{L}^{1}\right)_{2}\right]^{+}$constitute the primary objective of the present report. It may be worth noting in the present context that, although there are many iridium(III) complexes with bidentate ligands, only limited examples of iridium(III) complexes with tridentate ligands are available in the literature. ${ }^{14}$

\section{Experimental section}

\subsection{Materials}

Commercially available $\operatorname{IrCl}_{3} \cdot x \mathrm{H}_{2} \mathrm{O}$ was digested twice with concentrated $\mathrm{HCl}$ before use. The ligand 2-[(arylamino)phenylazo]pyridine was synthesized as reported earlier. ${ }^{6,7}$ Tetrabutylammonium perchlorate (TBAP) was prepared following the reported procedure. ${ }^{15}$ All chromatographic purification has been carried out on alumina and column chromatographic purification has been done using silica gel (60-120 mesh) LR. All other chemicals and solvents were of reagent grade and used as received.

\subsection{Physical measurements}

A Perkin-Elmer 240C elemental analyzer was used to collect microanalytical data $(\mathrm{C}, \mathrm{H}, \mathrm{N})$. The IR spectra were obtained using a Shimadzu FTIR-8400 spectrophotometer. ${ }^{1} \mathrm{H}$ and ${ }^{13} \mathrm{C}$ NMR spectra were measured with a Bruker Avance DPX 300 spectrometer using $\mathrm{SiMe}_{4}$ as an internal standard. PerkinElmer Lambda 950 spectrophotometer was used to record electronic spectra. Electrochemical measurements were performed at $298 \mathrm{~K}$ under a dry nitrogen atmosphere on a PC-controlled PAR model (370-4) electrochemistry system. ${ }^{10}$ All potentials reported herein are referenced to the saturated calomel electrode (SCE) and are uncorrected for junction contribution. The value for the ferrocenium-ferrocene couple under our conditions was $0.40 \mathrm{~V}$. The mass spectra were recorded on a Micromass LCT mass spectrometer equipped electrospray (ESI) system. 


\subsection{Synthesis of $\left[\operatorname{Ir}\left(L^{1 a}\right)\right] C l,[\mathbf{1}] C l$}

To a reddish brown mixture of $\mathrm{IrCl}_{3} \cdot \mathrm{xH}_{2} \mathrm{O}(105 \mathrm{mg}$, $0.30 \mathrm{mmol})$ and $\mathrm{HL}^{1 \mathrm{a}}(171 \mathrm{mg}, 0.62 \mathrm{mmol})$ in $40 \mathrm{ml}$ methanol, 2 drops of $\mathrm{NEt}_{3}$ was added. The mixture was refluxed on a steam bath for $5 \mathrm{~h}$ in nitrogen atmosphere. The resultant greenish brown solution was cooled and filtered. On evaporation of the filtrate a dark mass was obtained which was then loaded on a preparative alumina TLC plate for separation. The solvent mixture chloroform-acetonitrile $(2: 1)$ was used as eluent. A red band of unreacted ligand $\mathrm{HL}^{1 \mathrm{a}}$ moved first following by some minor green and brown bands. The major green band of $[\mathbf{1}] \mathrm{Cl}$ moved next which was collected and finally purified through silica gel column chromatography using $15 \%$ acetonitrile in chloroform. This green product was then recrystallised from dichloromethane-hexane mixture to get crystalline product. No other pure product could be isolated. Yield: $30 \%$. Analysis: Calc. for $\mathrm{C}_{34} \mathrm{H}_{26} \mathrm{~N}_{8} \mathrm{ClIr}$ : C, $52.74 ; \mathrm{H}, 3.38 ; \mathrm{N}, 14.47 \%$. Found: C, 52.86; H, 3.45; N, 14.61\%. ${ }^{1} \mathrm{H}$ NMR $\left(\mathrm{CDCl}_{3}, \delta\right): 6.38-6.46(m, 4 \mathrm{H}), 6.57-6.63(\mathrm{~m}, 4 \mathrm{H})$, $7 \cdot 03(d, 2 \mathrm{H}), 7 \cdot 14-7 \cdot 24(m, 12 \mathrm{H}), 7 \cdot 66(t, 2 \mathrm{H}), 7 \cdot 84$ $(d, 2 \mathrm{H}) .{ }^{13} \mathrm{C}$ NMR $\left(\mathrm{CDCl}_{3}, \delta\right): 115.5,118.5,121 \cdot 1$, $121.5,124 \cdot 0,127 \cdot 0,130 \cdot 0,137.9,141 \cdot 3,144 \cdot 4$, 144.8, 150.2, 172.2, 173.7. MS: m/z: $738\left[M_{c}-\mathrm{Cl}^{-}\right]^{+}$ $\left(M_{c}=\right.$ molecular complex, $\left.\left[\operatorname{Ir}\left(\mathrm{L}^{1 \mathrm{a}}\right)\right]^{+}\right)$.

The perchlorate salt of the cationic complex $[\mathbf{1}]^{+}$ was synthesized from its corresponding chloride salt. Addition of an aqueous solution of $\mathrm{NaClO}_{4}$ to the methanolic solution of $[\mathbf{1}] \mathrm{Cl}$ yielded $[\mathbf{1}] \mathrm{ClO}_{4}$ in almost quantitative yield $(>95 \%)$. The perchlorate salt formed X-ray quality crystals for its structure determination (see below).

The compound $\left[\operatorname{Ir}\left(\mathrm{L}^{1 b}\right)_{2}\right] \mathrm{Cl}$, [2] Cl was synthesized following a similar procedure using $\mathrm{HL}^{1 \mathrm{~b}}$ in place of $\mathrm{HL}^{1 \mathrm{la}}$. Yield: $28 \%$. Analysis: Calc. for $\mathrm{C}_{36} \mathrm{H}_{30} \mathrm{~N}_{8} \mathrm{ClIr}$ : C, $53.89 ; \mathrm{H}, 3.77 ; \mathrm{N}, 13.97 \%$. Found: C, 53.74; H, $3 \cdot 62 ; \mathrm{N}, 13.85 \% .{ }^{1} \mathrm{H}$ NMR $\left(\mathrm{CDCl}_{3}, \delta\right): 2.27(\mathrm{~s}, 6 \mathrm{H})$, 6.36-6.44 $(\mathrm{m}, 6 \mathrm{H}), 6.54-6.59(\mathrm{~m}, 2 \mathrm{H}), 6.97-7.03$ $(m, 8 \mathrm{H}), 7 \cdot 15(t, 2 \mathrm{H}), 7 \cdot 17-7.23(m, 2 \mathrm{H}), 7.65(t$, $2 \mathrm{H}), 7 \cdot 80(d, 2 \mathrm{H}) \cdot{ }^{13} \mathrm{C} \mathrm{NMR}\left(\mathrm{CDCl}_{3}, \delta\right): 21 \cdot 3,115 \cdot 6$, $118.4,120.9,121.6,124.3,128.9,130.7,137.9$, $141 \cdot 1,142 \cdot 5,144 \cdot 7,150 \cdot 1,172 \cdot 2,173 \cdot 9$. MS: $\mathrm{m} / \mathrm{z}$ : $766\left[M_{c}-\mathrm{Cl}^{-}\right]^{+}$.

\section{$2.4 X$-ray crystallographic analysis for $\left[\operatorname{Ir}\left(L^{1 a}\right)_{2}\right] \mathrm{ClO}_{4}$}

Suitable X-ray quality crystals of $[\mathbf{1}] \mathrm{ClO}_{4}$ were obtained by slow diffusion of a dichloromethane solu- tion of perchlorate salt of the compound into hexane. Intensity data were collected on a Bruker SMART diffractometer equipped with graphite monochromated Mo-K $\alpha$ radiation $(\lambda=0.71073 \AA)$. These were collected for Lorentz polarization effects. A total of 10033 reflections were collected out of which 6950 were unique $\left(R_{\text {int }}=0.0354\right)$ and used in subsequent analysis. The structure was solved by employing the SHELXS-97 package of programmes ${ }^{16}$ and refined by full matrix least squares based on $F^{2}$ (SHELXL-97). ${ }^{17}$ All the hydrogen atoms were located at the calculated positions.

\section{Results and discussion}

Two $\mathrm{HL}^{1}$ ligands, viz. 2-[(phenylamino)phenylazo] pyridine $\left(\mathrm{HL}^{1 \mathrm{a}}\right)$ and 2-[(p-tolylamino)phenylazo $]$ pyridine $\left(\mathrm{HL}^{1 \mathrm{~b}}\right)$, were used in this work. The reaction of the salt $\mathrm{IrCl}_{3} \cdot \mathrm{xH}_{2} \mathrm{O}$ with $\mathrm{HL}^{1}$ in boiling methanol afforded a brownish green mixture in about $5 \mathrm{~h}$. The reaction required vigorous degassing with nitrogen. A new green crystalline compound $\left[\operatorname{Ir}\left(\mathrm{L}^{1}\right)_{2}\right] \mathrm{Cl}$ was separated from the crude mass on a preparative TLC plate (alumina) using chloroformacetonitrile $(2: 1)$ mixture as an eluent. Lengthening of the reaction time seemed to increase the amount of by-products. There were many small overlapping bands, which could not be isolated in pure state and we do not consider these any further. The yields of the products were invariably low $(\approx 30 \%)$; and the green product was the only product isolable. The corresponding perchlorate salts of the above iridium complexes were obtained by metathesis and formed suitable X-ray quality crystals (see below).

Elemental analysis of the complexes showed satisfactory results and are collected in the experimental section. The positive ion ESI mass spectra of the complexes $[1] \mathrm{Cl}$ and $[2] \mathrm{Cl}$ showed intense peaks at $\mathrm{m} / \mathrm{z}, 738$ and $766 \mathrm{amu}$ respectively due to $[\mathrm{Mc}-\mathrm{X}]^{+}$ where $\mathrm{Mc}$ and $\mathrm{X}$ represent the cationic complex and the counter ion respectively. Notably, the observed isotopic distribution pattern for the ion, $\left[\operatorname{Ir}\left(\mathrm{L}^{1}\right)_{2}\right]^{+}$ conform very well with the simulated pattern. Segmented mass spectrum of $[\mathbf{1}]^{+}$and simulated isotopic pattern are displayed in figure 1 for comparison.

The diamagnetic iridium(III) complexes are $1: 1$ electrolytes in acetonitriles. ${ }^{18}$ These show highly resolved NMR spectra in $\mathrm{CDCl}_{3}$, which are in complete agreement with the X-ray structure of a representative complex $\left[\operatorname{Ir}\left(\mathrm{L}^{1 \mathrm{a}}\right)_{2}\right] \mathrm{ClO}_{4}$. There is a two-fold symmetry axis in the structure and thus the two-co- 
ordinated ligands in these complexes are magnetically equivalent. As a result the spectra are quite simple and resonances for only one ligand were observed. ${ }^{13} \mathrm{C}$ NMR spectrum of $\left[\operatorname{Ir}\left(\mathrm{L}^{1 \mathrm{a}}\right)_{2}\right] \mathrm{Cl}$ displayed fourteen distinct resonances with two resonances overlapped with each other. Four resonances were absent in DEPT spectrum of the same compound indicating the presence of four quaternary carbon atoms in the ligand. The spectral pattern of the $\left[\operatorname{Ir}\left(\mathrm{L}^{1 \mathrm{~b}}\right)_{2}\right] \mathrm{Cl}$ was as expected. ${ }^{13} \mathrm{C}$ NMR data are collected in the experimental section.

An ORTEP view and atom numbering scheme for the cationic part of the complex, $[\mathbf{1}] \mathrm{ClO}_{4}$ are shown in figure 2. Selected bond parameters and crystallographic data are collected in tables 1 and 2 respectively. The structural analysis reveals the presence of two anionic ligands $\left[\mathrm{L}^{1 \mathrm{a}}\right]^{-}$, each of which acts as an $\mathrm{N}, \mathrm{N}, \mathrm{N}$-tridentate donor with deprotonation of the secondary amine nitrogens $[\mathrm{N}(4)$ and $\mathrm{N}(8)]$. The geometry of the complex is meridional. The iridium atom sits on an imposed $\mathrm{C}_{2}$-axis bisecting the angles $\mathrm{N}(1)-\operatorname{Ir}(1)-\mathrm{N}(5)$ and $\mathrm{N}(4)-\operatorname{Ir}(1)-\mathrm{N}(8)$. The bond lengths within the ligand frame indicate the presence of extensive delocalisation of the anionic charge along the ligand backbone. Thus the nitrogen-carbon lengths on either side of the middle phenyl rings of

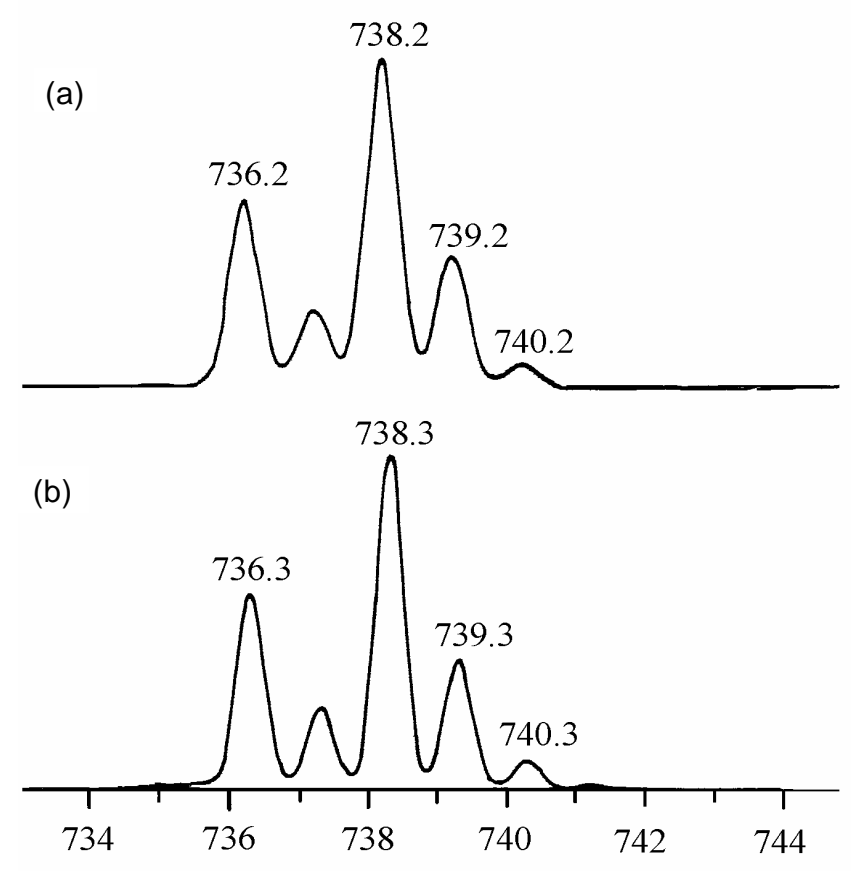

Figure 1. ESI mass spectrum of the complex $\left[\operatorname{Ir}\left(\mathrm{L}^{1 \mathrm{a}}\right)_{2}\right] \mathrm{Cl}$ : (a) calculated isotopic pattern and (b) observed spectrum. the ligands (viz. $\mathrm{C}(6)-\mathrm{N}(3)(1 \cdot 336(7) \AA), \mathrm{C}(11)-$ $\mathrm{N}(4) \quad(1.339(7) \AA)$ and $\mathrm{C}(23)-\mathrm{N}(7) \quad(1.371(7) \AA)$, $\mathrm{C}(28)-\mathrm{N}(8)(1.352(7) \AA))$ are appreciably shorter $^{3}$ than that observed in a related and uncoordinated ligand, 2-[2-(pyridylamino)phenylazo]pyridine $(\mathrm{C}-$ $\mathrm{N}$ length (average) 1.4095(4) $\AA$ ). Consequently the $\mathrm{N}-\mathrm{N}$ lengths are also elongated considerably. This affect is reflected in the lowering of $v_{\mathrm{N}=\mathrm{N}}$ frequencies in this complexes. While the $\gamma_{\mathrm{N}=\mathrm{N}}$ in the uncoordinated ligand appears ${ }^{3}$ near $1450 \mathrm{~cm}^{-1}$, it appears near $1385 \mathrm{~cm}^{-1}$ in the present iridium complexes. We also wish to note that the extent of delocalisation in the two ligands are different. As a result, the $\mathrm{N}(2)-\mathrm{N}(3)$ length $(1.323(6) \AA)$ is longer than $\mathrm{N}(6)-\mathrm{N}(7)$ length $(1.283(6) \AA)$ of the second ligand. Another notable observation in the structure is the significant shortening $^{19-21}$ of $\mathrm{Ir}-\mathrm{N}$ middle lengths viz. $\operatorname{Ir}(1)-\mathrm{N}(3)$ $(1.975(4) \AA)$ and $\operatorname{Ir}(1)-\mathrm{N}(7)(2 \cdot 000(5) \AA)$ with respect to $\mathrm{Ir}-\mathrm{N}$ (peripheral) lengths which lie in the range $2 \cdot 042(5)$ to $2 \cdot 062(5) \AA$.

The iridium complexes are freely soluble in common organic solvents like $\mathrm{CHCl}_{3}, \mathrm{CH}_{2} \mathrm{Cl}_{2}, \mathrm{CH}_{3} \mathrm{CN}$ etc. and produce bright green solutions. Electronic spectra of the two compounds, $[\mathbf{1}] \mathrm{Cl}$ and $[2] \mathrm{Cl}$ are shown in figure 3 and spectral data are collected in table 3. There are several absorptions spread over the visible and NIR region. Such low energy transitions in iridium(III) complexes are uncommon. ${ }^{22,23}$ To gain some insight into the nature of these transitions we have performed extended Hückel MO calculations with the crystallographic parameters of $\left[\operatorname{Ir}\left(\mathrm{L}^{1 \mathrm{a}}\right)_{2}\right] \mathrm{ClO}_{4}$ using the CACAO programme ${ }^{24}$ by Mealli and Proserpio. Due to obvious limitations, we note that the results are qualitative in nature. The calculations have indicated that the HOMO is a

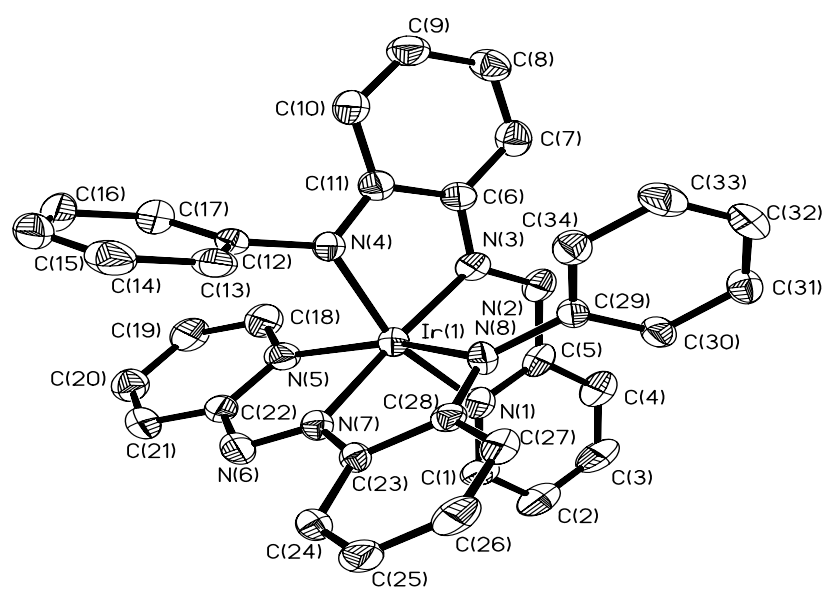

Figure 2. ORTEP representation for the cationic part of the complex $\left[\operatorname{Ir}\left(\mathrm{L}^{1 \mathrm{a}}\right)_{2}\right] \mathrm{ClO}_{4}$. 
Table 1. Selected bond distances $(\AA)$ and bond angles $\left({ }^{\circ}\right)$ of $\left[\operatorname{Ir}\left(\mathrm{L}^{1 \mathrm{a}}\right)_{2}\right] \mathrm{ClO}_{4}$.

\begin{tabular}{lccc}
\hline Selected bond distances & & & \\
$\operatorname{Ir}(1)-\mathrm{N}(1)$ & $2 \cdot 050(5)$ & $\mathrm{N}(3)-\mathrm{C}(6)$ & $1 \cdot 336(7)$ \\
$\operatorname{Ir}(1)-\mathrm{N}(3)$ & $1.975(4)$ & $\mathrm{C}(11)-\mathrm{N}(4)$ & $1.339(7)$ \\
$\operatorname{Ir}(1)-\mathrm{N}(4)$ & $2 \cdot 054(5)$ & $\mathrm{N}(4)-\mathrm{C}(12)$ & $1.428(7)$ \\
$\operatorname{Ir}(1)-\mathrm{N}(5)$ & $2 \cdot 062(5)$ & $\mathrm{C}(22)-\mathrm{N}(6)$ & $1.404(7)$ \\
$\operatorname{Ir}(1)-\mathrm{N}(7)$ & $2 \cdot 000(5)$ & $\mathrm{N}(6)-\mathrm{N}(7)$ & $1.283(6)$ \\
$\operatorname{Ir}(1)-\mathrm{N}(8)$ & $2 \cdot 042(5)$ & $\mathrm{N}(7)-\mathrm{C}(23)$ & $1.371(7)$ \\
$\mathrm{C}(5)-\mathrm{N}(2)$ & $1.431(8)$ & $\mathrm{C}(28)-\mathrm{N}(8)$ & $1.352(7)$ \\
$\mathrm{N}(2)-\mathrm{N}(3)$ & $1.323(6)$ & $\mathrm{N}(8)-\mathrm{C}(29)$ & $1.436(6)$ \\
& & & \\
Selected bond angles & & & \\
$\mathrm{N}(1)-\operatorname{Ir}(1)-\mathrm{N}(3)$ & $78.94(19)$ & $\mathrm{N}(5)-\operatorname{Ir}(1)-\mathrm{N}(7)$ & $76.85(18)$ \\
$\mathrm{N}(3)-\operatorname{Ir}(1)-\mathrm{N}(4)$ & $80 \cdot 14(18)$ & $\mathrm{N}(7)-\operatorname{Ir}(1)-\mathrm{N}(8)$ & $80.88(18)$ \\
\hline
\end{tabular}

Table 2. Crystallographic data of $\left[\operatorname{Ir}\left(\mathrm{L}^{1 \mathrm{aa}}\right)_{2}\right] \mathrm{ClO}_{4}$.

\begin{tabular}{ll}
\hline Empirical formula & $\mathrm{C}_{34} \mathrm{H}_{26} \mathrm{ClIrN}_{8} \mathrm{O}_{4}$ \\
Formula weight & $838 \cdot 28$ \\
Temperature (K) & $150(2)$ \\
Crystal system & Triclinic \\
Space group & $P-1$ \\
$a(\AA)$ & $9 \cdot 3139(4)$ \\
$b(\AA)$ & $10 \cdot 3089(5)$ \\
$c(\AA)$ & $17 \cdot 0070(8)$ \\
$\alpha\left({ }^{\circ}\right)$ & $104 \cdot 6950(10)$ \\
$\beta\left({ }^{\circ}\right)$ & $90 \cdot 4070(10)$ \\
$\gamma\left(^{\circ}\right)$ & $93 \cdot 6790(10)$ \\
$V\left(\AA^{3}\right)$ & $1575 \cdot 81(13)$ \\
$D_{\text {calc }}\left(\mathrm{Mg} / \mathrm{m}^{3}\right)$ & $1 \cdot 767$ \\
$Z$ & 2 \\
Crystal size $\left(\mathrm{mm}{ }^{3}\right)$ & $0 \cdot 28 \times 0 \cdot 18 \times 0 \cdot 06$ \\
GOF & $1 \cdot 064$ \\
Reflections collected & 10033 \\
Unique reflections & 6950 \\
Final $R$ indices $[I>2$ sigma $(I)]$ & $R 1=0 \cdot 0398, w R 2=0.0900$ \\
\hline
\end{tabular}

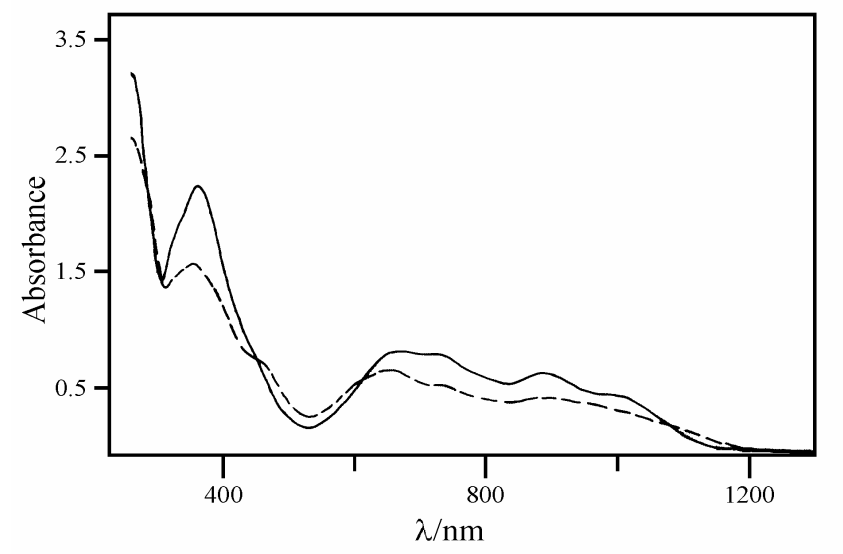

Figure 3. Solution spectra of $\left[\operatorname{Ir}\left(\mathrm{L}^{1 \mathrm{aa}}\right)_{2}\right] \mathrm{Cl}(-)$ and $\left[\operatorname{Ir}\left(\mathrm{L}^{1 \mathrm{~b}}\right)_{2}\right] \mathrm{Cl}(---)$ in dichloromethane (concentration: $\left.1.005 \times 10^{-4} \mathrm{M}\right)$. mixed metal-ligand orbital (with $47 \%$ metal and $43 \%$ ligand character). However, the HOMO-1, LUMO, LUMO+1 are all predominantly ligand orbitals and with relatively small metal contributions (table 4). Thus the low energy range bands in these complexes may be appropriately assigned to MLCT and/or LLCT transitions. In fact, such mixed descriptions in the MO's have been reported earlier, particularly for iridium-cyclometalated complexes. ${ }^{25}$

The complexes exhibit three reversible redox processes. Cyclic voltammogram of a representative complex [2] $\mathrm{Cl}$ is shown in figure 4 and the data are collected in table 3 . At negative potentials there are two reductive responses near -0.40 and $-0.90 \mathrm{~V}$ vs SCE respectively. We assign these to the successive reductions of the two coordinated ligands. Our assignment is further supported by MO calculations, which show that the LUMO is localized primarily on the coordinated ligand. For comparison, the free ligands undergo two-step reductions ${ }^{7}$ near -1.20 and $-2.00 \mathrm{~V}$ respectively. The anodic shift of reduction potentials in the iridium complexes as compared to the free ligand is due to coordinaton of the ligand to a trivalent metal ion. There is also a reversible oneelectron oxidation near $1.10 \mathrm{~V}$. This response cannot be simply assigned to metal oxidation. The molecular orbital calculations indeed showed that the highest occupied orbital (HOMO) is substantially delocalised over both metal and ligand orbitals. For comparison we note that the rhodium congener ${ }^{26}$ of the present iridium complex displayed an irreversible oxidation response near $1.40 \mathrm{~V}$. Moreover, the MO calculations on the $\left[\mathrm{Rh}\left(\mathrm{L}^{1}\right)_{2}\right]^{+}$indicated primarily a ligand orbital with small contributions of the metal orbitals. Though the present iridium complexes showed reversible cyclic voltammogram, our attempts to record 
Table 3. Spectral and electrochemical data.

\begin{tabular}{|c|c|c|c|c|c|}
\hline \multirow[b]{3}{*}{ Compound } & & & \multirow[b]{3}{*}{$\operatorname{Abs}^{\mathrm{a}}\left[\lambda_{\max }(\mathrm{nm})\left(\varepsilon / \mathrm{M}^{-1} \mathrm{~cm}^{-1}\right)\right]$} & \multicolumn{2}{|c|}{ Cyclic voltammetry $^{\mathrm{c}}$} \\
\hline & \multicolumn{2}{|c|}{$\operatorname{IR}(\mathrm{KBr})\left(v / \mathrm{cm}^{-1}\right)$} & & Oxidation & Reduction \\
\hline & $v_{\mathrm{C}=\mathrm{C}}, \mathrm{C}=\mathrm{N}$ & $\nu_{\mathrm{N}=\mathrm{N}}$ & & $E_{1 / 2}(\mathrm{~V})\left(\Delta E_{P}(\mathrm{mV})\right)^{\mathrm{d}}$ & $E_{1 / 2}(\mathrm{~V})\left(\Delta E_{P}(\mathrm{mV})\right)^{\mathrm{d}}$ \\
\hline 1 & 1600 & 1385 & $\begin{array}{c}1010(4515), 890(6590) \\
730(8135), 670(8365), \\
450(7515)^{\mathrm{b}}, 360(22330)\end{array}$ & $1 \cdot 10(80)$ & $0 \cdot 38(90), 0 \cdot 88(80)$ \\
\hline 2 & 1600 & 1385 & $\begin{array}{l}995(3570)^{\mathrm{b}}, 890(4535) \\
735(5345)^{\mathrm{b}}, 650(6695) \\
450(7515)^{\mathrm{b}}, 355(15570)\end{array}$ & $1 \cdot 02(60)$ & $0 \cdot 48(80), 0 \cdot 84(80)$ \\
\hline
\end{tabular}

${ }^{\mathrm{a}}$ Solvent $\mathrm{CH}_{2} \mathrm{Cl}_{2}$; ${ }^{\mathrm{b}}$ shoulder; ${ }^{\mathrm{c}}$ conditions: solvent $\mathrm{CH}_{2} \mathrm{Cl}_{2}$; supporting electrolyte TBAP $(0 \cdot 1 \mathrm{M})$; working electrode platinum; reference electrode $\mathrm{SCE}$; solute concentration $\approx 10^{-3}(\mathrm{M})$; scan rate $50 \mathrm{mVs}{ }^{-1} ;{ }^{\mathrm{d}} E_{1 / 2}=1 / 2\left(E_{p a}+E_{p c}\right) ; \Delta E_{p}=$ $\left(E_{p a}-E_{p c}\right)$

Table 4. Composition of molecular orbital.

\begin{tabular}{lccccc}
\hline & \multicolumn{4}{c}{$\%$ Contribution of fragments to } \\
\cline { 2 - 6 } Contributing fragments & LUMO+1 & LUMO & HOMO & HOMO-1 & HOMO-2 \\
\hline $\mathrm{Ir}$ & 18 & 19 & 47 & 28 & 58 \\
$\mathrm{~L}^{1 \mathrm{a}}$ & 78 & 77 & 43 & 65 & 29 \\
\hline
\end{tabular}

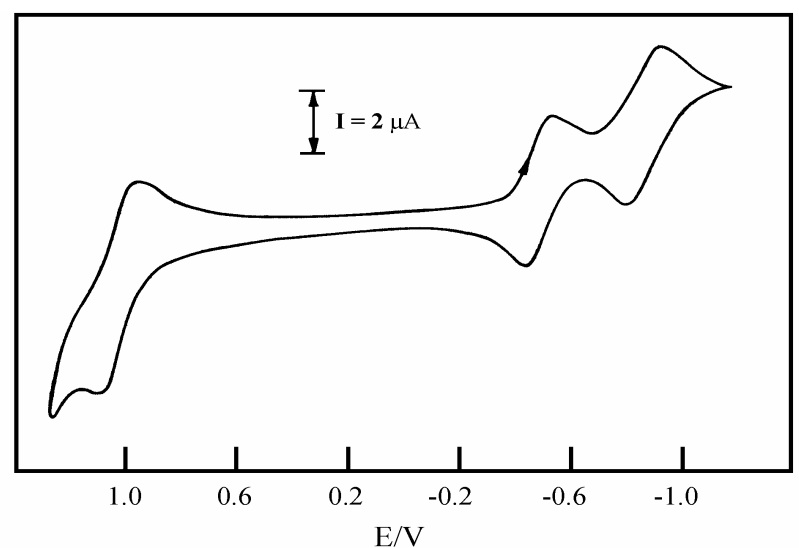

Figure 4. Cyclic voltammogram of $\left[\operatorname{Ir}\left(\mathrm{L}^{1 b}\right)_{2}\right] \mathrm{Cl}$ in dichloromethane (conc. $1 \mathrm{mmol}$, supporting electrolyte TBAP and scan speed $50 \mathrm{mVs}^{-1}$ ).

the EPR of the oxidized complexes were not successful. The oxidized complexes underwent rapid transformations to unidentified products.

\section{Conclusion}

The two iridium complexes, reported in this paper, constitute new examples of iridium complexes of azoaromatic ligands. Unusually, the complexes are green in colour and show charge transfer transitions in the extreme low energy part of the visible region. Extensive charge delocalisations in the present systems are believed to be responsible for these low energy transitions. Metal-ligand charge delocalisation is more common in the cyclometalated complexes of iridium(III). Electrochemical reversible redox processes at the mixed metal-ligand HOMO have been observed.

\section{Acknowledgements}

Financial support from the Council of Scientific and Industrial Research (CSIR), New Delhi is gratefully acknowledged. MP also thanks the CSIR for a fellowship.

\section{Supplementary material}

Crystallographic data for the $\left[\operatorname{Ir}\left(\mathrm{L}^{1 \mathrm{a}}\right)_{2}\right] \mathrm{ClO}_{4}$ complex in the CIF format has been deposited with the Cambridge Crystallographic Data Centre, CCDC No. 618077 for the $\left[\operatorname{Ir}\left(\mathrm{L}^{1 \mathrm{aa}}\right)_{2}\right] \mathrm{ClO}_{4}$ complex. 


\section{References}

1. Das S, Banerjee P, Peng S-M, Lee G-H, Kim J and Goswami S 2006 Inorg. Chem. 45562

2. Sanyal A, Banerjee P, Lee G-H, Peng S-M, Hung $\mathrm{C}-\mathrm{H}$ and Goswami S 2004 Inorg. Chem. 437456

3. Kamar K K, Das S, Hung C-H, Casteñeiras A, Kuźmin M D, Rillo C, Bartolomé J and Goswami S 2003 Inorg. Chem. 425367

4. Kamar K K, Saha A, Casteñeiras A, Hung C-H and Goswami S 2002 Inorg. Chem. 414531

5. Kamar K K, Saha A and Goswami S 2002 Proc. Indian Acad. Sci. (Chem. Sci.) 114339

6. Saha A, Ghosh A K, Majumdar P, Mitra K N, Mondal S, Rajak K K, Falvello L R and Goswami S 1999 Organometallics 183772

7. Saha A, Majumdar P and Goswami S $2000 \mathrm{~J}$. Chem. Soc., Dalton Trans. 1703

8. Saha A, Majumdar P, Peng S-M and Goswami S 2000 Eur. J. Inorg. Chem. 2631

9. Das C, Saha A, Hung C-H, Lee G-H, Peng S-M and Goswami S 2003 Inorg. Chem. 42198

10. Goswami S, Mukherjee R and Chakravorty A 1983 Inorg. Chem. 222825

11. Bryndza H E and Tam W 1988 Chem. Rev. 881163

12. Fryzuk M D and Montgomery C D 1989 Coord. Chem. Rev. 951

13. Panda M, Das C, Lee G-H, Peng S-M and Goswami S 2004 Dalton Trans. 2655
14. Yutaka T, Obara S, Ogawa S, Nozaki K, Ikeda N, Ohno T, Ishii Y, Sakai K and Haga Masa-aki 2005 Inorg. Chem. 44 4737, and references therein

15. Sawyer D T and Roberts J L Jr 1974 Experimental electrochemistry for chemists (New York: Wiley) pp 167-215

16. Sheldrick G M 1990 Acta Crystallogr. A46 467

17. Sheldrick G M 1997 SHELXL-97 Program for the refinement of crystal structures, University of Göttingen: Göttingen, Germany

18. Geary W J 1971 Coord. Chem. Rev. 781

19. Bruin B De, Bill E, Bothe E, Weyhermuller T and Wieghardt K 2000 Inorg. Chem. 392936

20. Matsumoto N, Motoda $Y$, Matsuo T, Nakashima T, Re N, Dahan F and Tuchagues J-P 1999 Inorg. Chem. 381165

21. Pramanik N C, Pramanik K, Ghosh P and Bhattacharya S 1998 Polyhedron 171525

22. Allen G C, El-Sharkawy G A M and Warren K D 1972 Inorg. Chem. 1151

23. Acharyya R, Basuli F, Wang R-Z, Mak T C W and Bhattacharya S 2004 Inorg. Chem. 43704

24. Mealli C and Proserpio D M 1990 J. Chem. Educ. 67 399

25. Poison M, Fracasso S, Bertolasi V, Ravaglia M and Scandola F 2004 Inorg. Chem. 431950

26. Das C, Ghosh A K, Hung C-H, Lee G-H, Peng S-M and Goswami S 2002 Inorg. Chem. 417125 